\title{
7. City-Governance: conceptualizing digital maturity model
}

\section{Dr. Tetiana Fesenko}

Associate Professor

Department of Engineering and Architecture

Luhansk National Agrarian University, Kharkiv, Ukraine,

ORCID iD: https://orcid.org/0000-0001-9636-9598

E-Mail: FesenkoTatyana@gmail.com
Dr. Galyna Fesenko

Associate Professor

Department of History and Cultural Studies

O. M. Beketov National University of Urban Economy in

Kharkiv, Ukraine,

ORCID iD: https://orcid.org/0000-0001-7133-484X

E-Mail: Galyna.Fesenko@kname.edu.ua

\section{Abstract:}

The article aims to outline the role of ICT in urban management. The digital segment is presented as significant for making cities sustainable, and for expanding access to basic services for large numbers of people. The matrix of ICT-tools in relation to sustainable cities development targets is developed. The comparative review of Digital City, Intelligent City, and Smart City is provided. The municipal egovernment data of international ratings are analyzed with the special focus on aspects of online services management. The existing digital gaps between cities are pointed out in terms of e-governance maturity. It is proposed the maturity model of the municipal digital office, which it consists eight levels of the functional responsibility for urban online services development.

\section{Keywords:}

e-governance; digital city; municipal digital office; online service; GIS

Vol. 5 No. 2 (2017)

Issue- June 


\section{City-Governance: conceptualizing digital maturity model}

\section{Introduction}

Digital cities represent the best entry point for pursuing Sustainable Development Goals. The local e-governments have the proximity to translate the principles of good urban governance to effectively manage, govern and develop a city and to ensure equitable access to citizenship. Egovernance is used ICT tools with which to reach a wider population through various online service deliveries and options, including mobile devices (UN-HABITAT, 2015 : 7). With the help of ICT, it is possible to improve the level of provision of municipal services, the transparency of government and the level of trust in it by citizens, and generally positive influence the competitiveness and well-being of society. Therefore, UN recommends using the ICT tools with which city governments are able to implement and deliver decisions within a complex urban environment.

However, the insufficient level of e-governance is a challenge facing towns and cities globally. The local governments are increasingly being recognized that new complexities of cities of today require a constant and fluid online dialogue between institutions, on the one side, and between people and institutions, on the other. Information and communication technology (ICT) can become a catalyst to improve governance in towns and cities, as the benefit of such technology is the maximization of rapid and effective information transfer to communities and individuals. ICT helps increase the levels of participation, efficiency and accountability in public urban policies, provided that the tools are appropriately used.

This article aims at modeling of the local e-governance through analyzing of city digital development levels. To attain such objective, the comparative review of the e-government progress in Digital City, Intelligent City, and Smart City is provided. The maturity model of integrating egovernance components into the socio-technical system of online municipal services is developed.

\section{e-Government as a tool of Urban Sustainable Development}

The use of ICTs in government can effectively support an integrated and inclusive implementation of the SDGs, including Goal 11 "Sustainable cities and communities" (United Nations E-Government Survey, 2016:144-146). This is due to ICTs cross-cutting contributions to making cities inclusive, safe, resilient and sustainable. Local governments integrate aspects of e-governance into their operations, ranging from basic websites to sophisticated, interactive online platforms. Developing an e-governance framework that incorporates accountability, social inclusion, and

Vol. 5 No. 2 (2017)

Issue- June 
sustainable practices into urban governance provide a useful starting point for municipalities (Table 1).

Table 1: Matrix of ICT-tools used in relation to Sustainable Development Goal № 11: Sustainable cities and communities

Targets
11.1. By 2030, ensure access for all to adequate, safe and
affordable housing and basic services and upgrade slums

11.2. By 2030, provide access to safe, affordable, accessible and sustainable transport systems for all, improving road safety, notably by expanding public transport, with special attention to the needs of those in vulnerable situations, women, children, persons with disabilities and older persons 11.3. By 2030, enhance inclusive and sustainable urbanization and capacity for participatory, integrated and sustainable human settlement planning and management in all countries

\section{ICT-tools}

Online information and service provision in the sectors of health, education, social, labour, finance and housing maintenance utilities

Open access of GIS applications for everyone, with possibility to use databases of various contextual data for create safe mobility by public transport

Online information and service provision with special attention to the needs of those in vulnerable situations, women, children, persons with disabilities and older persons. City GIS map with indicators of unique environment contexts and stakeholders needs. E-participation, i.e., use of online services to engage citizens and noncitizens including through provision of interaction with stakeholders (econsultation) and engagement in decision-making processes (edecision making)

Vol. 5 No. 2 (2017)

\section{Issue- June}


11.4. Strengthen efforts to protect and safeguard the world's cultural and natural heritage

11.5. By 2030, significantly reduce the number of deaths and the number of people affected and substantially decrease the direct economic losses relative to global gross domestic product caused by disasters, including waterrelated disasters, with a focus on protecting the poor and people in vulnerable situations

11.6. By 2030 , reduce the adverse per capita environmental impact of cities, including by paying special attention to air quality and municipal and other waste management

11.7. By 2030, provide universal access to safe, inclusive and accessible, green and public spaces, in particular for women and children, older persons and persons with disabilities
Electronic document management, which contains information about the cities cultural and natural heritage, as well as the rules for their use.

Online information related to environmental protection and climate change with GIS mapping of vulnerable communities

Electronic eco-monitoring, with the installation of sensors for analysis of air quality.

Online service, which allows citizens to learn about the ecological security of this or another neighborhoods, with an available beta version on an interactive map.

Electronic municipal waste management, including garbage cans with filling sensors.

GIS monitoring of architectural and spatial solutions of green and public spaces in terms of a safe, inclusive and accessible city.

Cities have adopted ICT tools presented on municipal websites aimed at providing information, services or communication with citizens. Since the modern city is a complex,

Vol. 5 No. 2 (2017)

Issue- June 
territorially-distributed, socioeconomic and economic system, its management requires the creation and implementation of geographic information system (GIS). GIS is a computer system designed to capture, store, manipulate, analyze, manage, and present a variety of spatial and geographical data.

The basic structure of the city's GIS database is as follows:

- the unified cartographic basis with a register of geographical names (streets, rivers), strata of buildings and structures, etc;

- the thematic information resources are supplemented with the corresponding attributive component: the network of engineering communications, natural resources, the register of the cultural and natural heritage, medical, educational institutions, and other urban infrastructure;

- complex or problem-oriented information resources: zones of restricted development (water protection, nature protection and sanitary protection zones, red lines), a section of the road on which repairs are carried out, etc.

GIS is also a Geographical Business Intelligence tool devoted to the re-design of the territory, which is conceived as a unique platform with different entry points, both private and public: for local authorities, professionals, and citizens.

City GIS provides support for maximally justified management decisions on urban planning and territorial development on the basis of rapid access to all subjects operating in the city, full of objective information on available territorial resources. Urban planning requires including many layers of detail on a single map, and one of the features of a GIS is multi-layered mapping. Each of these layers has different types of information and data associated with it. Thus, a municipal planning committee can use a GIS to see a variety of different things. This multilayered capability can make a big difference when developing an area.

GIS is also a Geographical Business Intelligence tool devoted to the re-design of the territory, which is conceived as a unique platform with different entry points, both private and public: for local authorities, professionals, and citizens. Fixing the social form through GIS-focus allows you to synchronize and combine elements that have been disconnected. GIS allows to model social integration and socio-spatial design on the principles of balancing the interests of social groups. Cities must form such locations that exclude any discrimination. It is also noted that the city should ensure equality in the "right to the city" for all members of the urban community, regardless of age, sex, race, property status, etc.

In general, the benefits of using a GIS in urban planning are numerous, because GIS takes into consideration many different factors to help build an efficient and organized city.

\section{Digital City. Intelligent City. Smart City}

Cities around the world are developing different types of urbanization models, strategically relying on the use of digital technologies. Depending on the context of the vision of urban

Vol. 5 No. 2 (2017)

Issue- June 
development and the ways in which digital technologies support the city, such models can be called Digital City, Intelligent City, Smart City (Estevez E., Lopes N. \& Janowski T., 2016 : 10-12). A Digital City is clearly based on the integration of digital technology into the city infrastructure: informatics (communication), city portals for online information services. Intelligent Cities have intelligent systems (functionality), online web-based e-learning systems integrated and interoperable with other city platforms. Smart Cities besides technology integration also include innovation (advanced visualization and simulation tools), e-Learning platform and knowledge management, and benchmarking requirements (Smart Cities, 2014). The major difference between Intelligent Cities and Smart Cities is the special focus of the latter on social and human concerns (quality of life) and ecological systems (sustainability).

City's well-developed fiber network is one of the pre-conditions to e-services. The goal of the city's fiber network efforts is to build a competition infrastructure capable of meeting future communication needs, spur economic activity, diversity and freedom of choice, as well as minimizing disruption to the city's streets. It should be noted that many local governments have concentrated on e-portals and citizens' access to government services to obtain items such as licenses, permits, and records. These early developments were characterized by the generic term "e-government", which concentrated on increasing the efficiency of government operations and services through the Internet (Internet-based applications).

However, there is a difference between this (e-government) and e-governance, the latter being a broader concept including the use of ICT by various actors in society to enhance citizen engagement in expressing a voice, making choices, and shaping political institutions. Indeed eparticipation expands a government's toolbox for reaching out to and engaging with its people, but it does not replace traditional forms of public participation (whether through face-to-face meetings, paper-based communications, telephone calls, and physical bulletin boards, among other offline modalities). Rather, participle culture is reflected in how governments deploy the optimal mix of online and offline modalities within their jurisdictions to reach the various social groups among its population.

The concept of Smart City is based on "Smart Governance" (Estevez E., Lopes N. \& Janowski T., 2016 : 11), structurally consisting of: participation in decision-making, public and social services, transparent governance, political strategies \& perspectives (Estevez E., Lopes N. \& Janowski T., 2016 : 12). The Smart Governance represents how the Smart City government operates, how it manages public funds, how it delivers public infrastructure and services, how it supports sustainable city development, and how it engages its citizens in decision-making processes. The public governance in a city and the delivery of public services should be provided in efficient, effective, transparent, open and collaborative ways. For example, openness and transparency of decisions can be ensured by using the online service "open budget", in which the data is downloaded into the system every day automatically.

Vol. 5 No. 2 (2017)

Issue- June

ISSN 2347-6869 (E) \& ISSN 2347-2146 (P)

City-Governance: conceptualizing digital maturity model by Tetiana Fesenko, Galyna Fesenko Page no. 106-122 
Smart City development should be produced through participatory governance mechanisms, such as creating citizen-centric, efficient, accountable, transparent, inclusive, creative city, with a sense of safety and security. The researchers have noticed that "the government needs to invest more in strengthening capacity building as a demand side uptakes for interactive Government to citizen as well as Citizen to Government e-service delivery and its extend usage to achieve social, environmental and economic sustainability" (Chandra S., 2016).

Participatory governance may rely on mechanisms such as interest group meetings, hearings, and community involvement in budgeting and planning. The local public, including the news media, has ready access to documents. Citizens are generally informed and provide input into key local decisions directly at public meetings, perhaps through surveys, occasional referenda, or other means. Civil society groups reflecting the composition of the community, interact regularly with local authorities. Residents tend to participate voluntarily in neighborhood improvements. In short, citizens generally participate in decisions that affect their quality of life (UN-HABITAT, 2004 : 22). Generally, centralized and comprehensively strategized e-governance should allow for more effective and optimized coordination and control of Smart City functions and operations. It is necessary to make full use of the potential offered by digitization and pursue a vision of Smart Sustainable City (Estevez E., Lopes N. \& Janowski T., 2016 : 12).

\section{Local E-Governance evaluation}

An extremely important part of Urban E-Governance is also learning from other cities, e.g., through the bench-learning, defining measurable goals and indicators, and deploying monitoring mechanisms to assess to what extent the goals are being met. The level of implementation of egovernment tools by cities is assessed using special methods, which are used to compile the relevant city ratings. The MeGAP (The Municipal E-Government Assessment Project) is an assessment tool for US municipal websites emphasizing online service provision. It surveyed 38 American cities with a population between one and two hundred thousand people and developed a rubric for evaluating them. Functional performance dimensions were: 1) Information dissemination (city codes, minutes, traffic information, municipal government directory); 2) Interactive functions (bidder applications, downloadable forms, building permit process, business license); 3) E-Commerce functions (utility payment, tax lookup and payment, code enforcement); 4) E-Democracy (e-meetings, e-forums, user customization) (Kaylor C. H., 2005).

The UN Digital Governance in Municipalities seems to be the most solid because it is comprehensive and assesses five important components (security and privacy, usability, content, services, and citizen participation). This continuing research evaluates the websites of municipalities in terms of digital governance and ranks them on a global scale. Simply stated, digital governance is comprised of both digital government (delivery of public services) and digital democracy (citizen

Vol. 5 No. 2 (2017)

Issue- June

ISSN 2347-6869 (E) \& ISSN 2347-2146 (P)

City-Governance: conceptualizing digital maturity model by Tetiana Fesenko, Galyna Fesenko Page no. 106-122 
participation in governance). The research focuses on cities throughout the world based on population size and the total number of Internet users in each nation. The identification of cities based on these factors proceeded through the utilization of statistics published by the International Telecommunication Union (ITU), an organization affiliated with the United Nations (UN). To determine the 100 most wired nations worldwide, information on the total number of online users was compiled from the ITU-UN. In each country, the largest city by population was then selected as a surrogate for all cities in that country (Holzer M. \& Manoharan A.P., 2016 : 9).

The focus of the evaluation is the main city homepage of each of the countries evaluated. This is defined as the official website where information about city administration and online services are provided by the municipality. Worldwide, municipalities are constantly improving their official websites as they are the primary interface with citizens in the e-government paradigm. A municipal website should include information about available city services, along with such information related to the city council, mayor, and executive branch, as well as other departments and services. Citizen and Social Engagement remained as the category with the lowest average score. These results show that cities have too often been hesitant to adopt citizen-centric participatory egovernance services, and have yet to recognize the importance of involving and supporting citizen participation online (Holzer M. \& Manoharan A.P., 2016 : 36).

Based on the 2015-16 evaluation, Seoul, Helsinki, Madrid, Hong Kong, and Prague have the highest evaluation scores. (Holzer M. \& Manoharan A.P., 2016 : 4). The results of the overall rankings are separated by continent The top-ranked cities for each continent are Johannesburg (Africa), Seoul (Asia), Helsinki (Europe), New York (North America), Auckland (Oceania), and Buenos Aires (South America). (Holzer M. \& Manoharan A.P., 2016 : 21). The governments of many cities continue to look for ways to increase the efficiency and effectiveness of digital transformations, on the one hand, taking into account their positions in global indices, and on the other hand, outlining the national features of e-government readiness (Fesenko T. \& Fesenko G., 2016; Fesenko G. \& Fesenko T., 2017). After all, e-government programs in each city are carried out in special national conditions, where the software environment is represented by a set of specific external and internal factors constraining or accelerating the digital development.

At the same time, global indices clearly demonstrate the general trend of slow development of digital transformations in most cities, and moreover, an increase in the "digital divide" with cityleaders. In order to create a reliable basis for an objective assessment of the level of e-maturity of city government, it is necessary to develop an appropriate analytical and empirical justification for determining its digital level. And this requires attention to the main components of the development management of Smart City, such as the creation of a central agency responsible for coordination of initiatives, well-designed governance model, enabling continuous improvements. In particular, the creation of a unified central office to drive e-government operations is important for organizational integration with digital platforms of local government.

Vol. 5 No. 2 (2017)

Issue- June

ISSN 2347-6869 (E) \& ISSN 2347-2146 (P)

City-Governance: conceptualizing digital maturity model by Tetiana Fesenko, Galyna Fesenko Page no. 106-122 


\section{Maturity model of Municipal Digital Office}

Regardless of the e-development model adopted, the Municipal Digital Office should deploy in pursuit of sustainability in leveraging digital technology for formulating and implementing city programs and projects. Maturity models Municipal Digital Office is considered as part of the egovernance transformation, and represent the advancement of Smart City development along a series of discrete maturity stages, the achievement of higher stages, the achievement of higher stages representing a significant advancement compared to the lower stages. It is proposed to use the models of the Project Management Office (PMO) (Kendall G.I. \& Rollins S.C., 2003), as a conceptual model for assessing the maturity of Municipal Digital Office. As it is known, project management is regarded as a strategic competency for the organization. and, as such, can significantly improve the organization's future competitiveness. There are such PMO models (Kendall G.I. \& Rollins S.C., 2003 : 285):

1. Project Repository Model (a low or no value model). It allows identifying gaps in the existing information and bottlenecks in the performance of all projects, and strengthen risk control of projects by stages of implementation cycles.

2. Coach Model (a tactical model that can provide some value for a short time). It is a coordination center for communications between functional units. It is responsible for documenting best practices and actively monitoring the progress and characteristics of projects. It provides consultations to performers in accelerating project completion deadlines.

3. Enterprise Model (a strategic model oriented to central control of all major projects). It is a permanent office, in which the management of all projects of the organization is concentrated.

\section{4. “Deliver Now" Model (a high-value strategic model focused on throughput, delivery} acceleration and choosing the right projects): It manages of Portfolio projects, including checking its compliance with the objectives of the organization and its assets, monitors the current distribution of loads, prioritizes all current and planned projects.

The PMO model contains such levels of maturity: I - PMO defining value; II - PMO organized; III - Searching for delivery value; IV - Portfolio management; V - Community buy-in; VI Project teams delivering on schedule; VII - Project teams calibrated w/portfolios; more projects in fiscal year; VIII - Organization delivering (Kendall G.I. \& Rollins S.C., 2003:373). The level of maturity depends on the degree and nature of the application of the project management processes established by the A Guide to the project management body of knowledge (PMBOK® Guide, 2013): Integration Management; Scope Management; Time Management; Cost Management; Quality Management; Human Resource Management; Communication Management; Risk Management; Procurement Management; Stakeholder Management (Table 2).

Vol. 5 No. 2 (2017)

Issue- June 


\section{Table 2: Municipal Digital Office (MDO) maturity model (Levels I - IV).}

Levels Knowledge areas

of MDO Project

Maturity Management

Integration

Management

Scope Management

Quality Management

\section{Level I}

Level II

Management

Risk Management

Stakeholder Management

Integration

Management

Scope Management

Quality Management

\section{ICT content of municipal organizational maturity}

No standard and tools for development management of online services.

The municipality uses GIS-tools informally, selectively, and to perform certain functions.

No clear understanding and control of the development of city online-service.

No requirement of stakeholders (including beneficiaries) for the city online-service.

The executors of the city online-service are subordinate to the heads of the municipal. functional divisions.

Their level of ICT using is unknown.

The executors of the city online-service are sought as tasks begin instead of pre-planned.

Communication No standardized reporting on the level of e-government reporting on the online services development.

Risks of online services development are not specifically considered. No standardized reporting on the identification of all egovernment stakeholders. The criteria "cost" and "time" are used to take into account the specifics of the online services development.

Technical specification for online services is developed by a separate department (MDO). MDO mentors demonstrate readiness to identify the stakeholder's needs in municipal online services.

The role of the staff of the municipal functional departments in the provision of specific online services is not clearly

Human Resource defined.

Management MDO mentors are available to help the municipal functional departments determine customer needs and are assigned to the most important strategic online services as an ICT/GIS

Vol. 5 No. 2 (2017)

Issue- June 


\begin{tabular}{|c|c|}
\hline & subject matter expert. \\
\hline $\begin{array}{l}\text { Communication } \\
\text { Management }\end{array}$ & $\begin{array}{l}\text { The municipality periodically reviews the level of e- } \\
\text { governance by developing online services. }\end{array}$ \\
\hline Risk Management & $\begin{array}{l}\text { The main risks of managing online service development are } \\
\text { revealed. }\end{array}$ \\
\hline $\begin{array}{l}\text { Stakeholder } \\
\text { Management }\end{array}$ & $\begin{array}{l}\text { It is developed the register of stakeholders on-line-services, } \\
\text { with special attention to the needs of those in vulnerable } \\
\text { situations, women, children, persons with disabilities and } \\
\text { older persons. }\end{array}$ \\
\hline $\begin{array}{l}\text { Integration } \\
\text { Management }\end{array}$ & $\begin{array}{l}\text { At meetings, the e-development management team (MDO } \\
\text { mentors and municipality functional managers) applies } \\
\text { standard procedures to identify opportunities and threats to } \\
\text { provide online services. }\end{array}$ \\
\hline
\end{tabular}

Scope Management

Functional requirements for smart services are reflected in the components of e-services.

The processes of documenting the smart service are partially accompanied by the use of GIS-tools.

E-development management team (MDO and municipality

Quality Management functional managers) is aimed at satisfying the needs of beneficiaries in smart services.

E-development management team (MDO and municipality

Level III functional managers ) is focused on meeting customer needs that affect the Urban Sustainable Development goals.

Human Resource

Management Team members are learning and developing their new attitudes in considering their personal work delivery speed and attempting to stay on the critical path of the projection which they are working. Regular meetings are held in the municipality on monitoring Communication the level of development of online services.

Management Developed ways to improve the management of city online services on the GIS platform.

Known opportunities to increase the response to risk

Risk Management management of city online services on the GIS platform.

Stakeholder E-development management team (MDO and municipality

Management functional managers) defines the basic requirements and

Vol. 5 No. 2 (2017)

Issue- June ISSN 2347-6869 (E) \& ISSN 2347-2146 (P)

City-Governance: conceptualizing digital maturity model by Tetiana Fesenko, Galyna Fesenko Page no. 106-122 
expectations, the degree of influence of each of stakeholders groups.

The standard procedures, change management, tracking egovernance indicators are developed.

Integration

Management

Scope Management

Level IV

Human Resource

Management

Quality Management

Management

Risk Management

Action plans to reduce risks in the management of urban

Stakeholder

Management inclusive smart services.

E-development management team (MDO and municipality

Conformance indicators of E-governance to sustainable urban development goals are displayed in relevant databases.

The different contents of layers of GIS, which are available in online are developed.

The dependencies between the content of various types of smart services are established.

GIS-layers are the basis for creating various online services are developed.

E-development management team (MDO and municipality functional managers) is aware of the specific beneficiaries needs in smart services.

MDO specialists conduct training about advanced features of GIS-tools for municipal functional departments (community) and other users of smart services.

All urban projects stakeholders develop competence for using GIS tools and mobile apps.

E-development project managers are competent in the information about the interdependence between various elements of smart services.

GIS-tools functionality is determined.

The information support for the formation of different content databases, the development of inclusive GIS-layers is provided.

The information about city services is available on the municipal site in online mode. functional managers) the requirements and expectations, the impact of stakeholders on the effectiveness of smart-services. All information about stakeholders is decomposed taking into account the inclusive factor.

Vol. 5 No. 2 (2017)

Issue- June 
Interaction with stakeholders is supported using onlineservices.

Level I. MDO is able to effectively implement information service projects. Its role is consulting, informational support of the functional units of the municipality in the use of ICT (including GIS). It forms different content databases, provides expert evaluation of the implementation of a complex of electronic databases, as well as assistance in understanding and operating IT terminology, mastering the staff of the municipality of specific software tools. The level of application of ICT in municipal services is explored. Technical-economic-social evaluation of the utility of MDO is developed.

Level II. MDO analyzes how in the municipality online services are organized, as functional units use GIS for internal using (for example, for land allotment projects). Engineering and reengineering of internal processes are conducted, the audit of project activities is carried out by functional departments. The system of electronic databases is widely used, it allows to receive crosssectional information. At the same time, the systematic and orderly activity of municipal employees, in particular, the competence to provide services using GIS, is increasing. The participation of beneficiaries (community) in urban online services is very limited and weak.

Level III. MDO: the development of ways to effectively perform online services. It uses the potential of the municipal functional departments to use ICT for online services. The municipal functional departments use the MDO as an information source to learn and develop their own strategies (the development of e-governance services, improvement of quality and participation of city smart-services). At this level of maturity, a "foundation" is laid for the use of GIS-mapping by external customers - city residents.

Level IV. MDO requires a high level of e-government maturity, which opens up "accelerated access" to citizenship e-participation on the GIS platform. Mobile apps with various inclusive content, in particular, safety mobility for women and children, older persons and persons with disabilities (Fesenko T., Fesenko G. \& Bibik N., 2017) are integrated. MDO of this level is responsible for developing smart services for urban programs and projects. MDO`s competence is included:

- coordination of project / program teams;

- completion of linear project / program commands with necessary ICT-, GIS-tools;

- coordinating the exchange of information between all stakeholders groups in urban projects;

- inclusive benchmarking, which improves the processes, procedures, operations, models, methods, and tools of the project activity;

Vol. 5 No. 2 (2017)

Issue- June 
- $\quad$ receiving inclusive smart-services, contain an additional value.

Level $\boldsymbol{V}$. Municipality employees as members of the Project Team are making progress in the functional efficiency of providing urban smart services. ICT, GIS is used at all stages of the lifecycle of projects that develop smart-services. Project teams aware of their responsibility for the financial performance of urban smart services projects. They promote cost-effective and customer-focused budgeting of smart-services.

Level VI. MDO has reached a point where most of the services are provided using ICT, GIS. It is characterized by the achievement of obvious improvements in the participation through smart services. Most smart-services of a city are available to the community, as well as performed on time and in full. The best practices are documented and used for benchmarking and dissemination. Marketing of the successes is vital to keep motivating all project teams and functional managers. MDO`s competence is included:

- improving the competence of project/program teams in using new versions of IST, developing new layers for GIS-maps;

- the creation of new blocks of inclusive sensitive databases and the maintenance of a centralized exchange of its information between all stakeholders groups of service projects;

- to monitor the implementation of processes, procedures, operations, as well as the use of models, techniques, and tools in projects for the creation of e-services;

- $\quad$ to improve smart services containing additional value (including inclusive).

Level VII. MDO: Wide range of smart-services. The municipality benefits from MDOs in the form of client-oriented use of budgetary funds, the provision of smart-services on time and on schedule, as well as the high level of participation and community satisfaction. All smart-services are integrated, which makes it possible to predict how changes to one service (service group) will affect the state of another municipality's service (service groups), and progress in achieving sustainable urban development goals.

Level VIII. All the municipal services are provided with the maximum using ICT, GIS. The required interactive GIS layers are created. Most of the community use mobile GIS applications and are involved in decision-making processes for city projects. The municipality introduced a process of continuous improvement using ICT, GIS to identify the most effective ways to improve the quality of smart-services. More than $95 \%$ of smart-services are highly valued by the beneficiaries, and $10 \%$ of these services - even exceed the expectations of the beneficiaries.

Vol. 5 No. 2 (2017)

Issue- June 
The present MDO models demonstrate the level of the function responsibility from advisory support for the project to the constant introduction online services. Figure 1 illustrates the MDO's maturity pathway, focusing on how to use the knowledge project management for the city online services development.

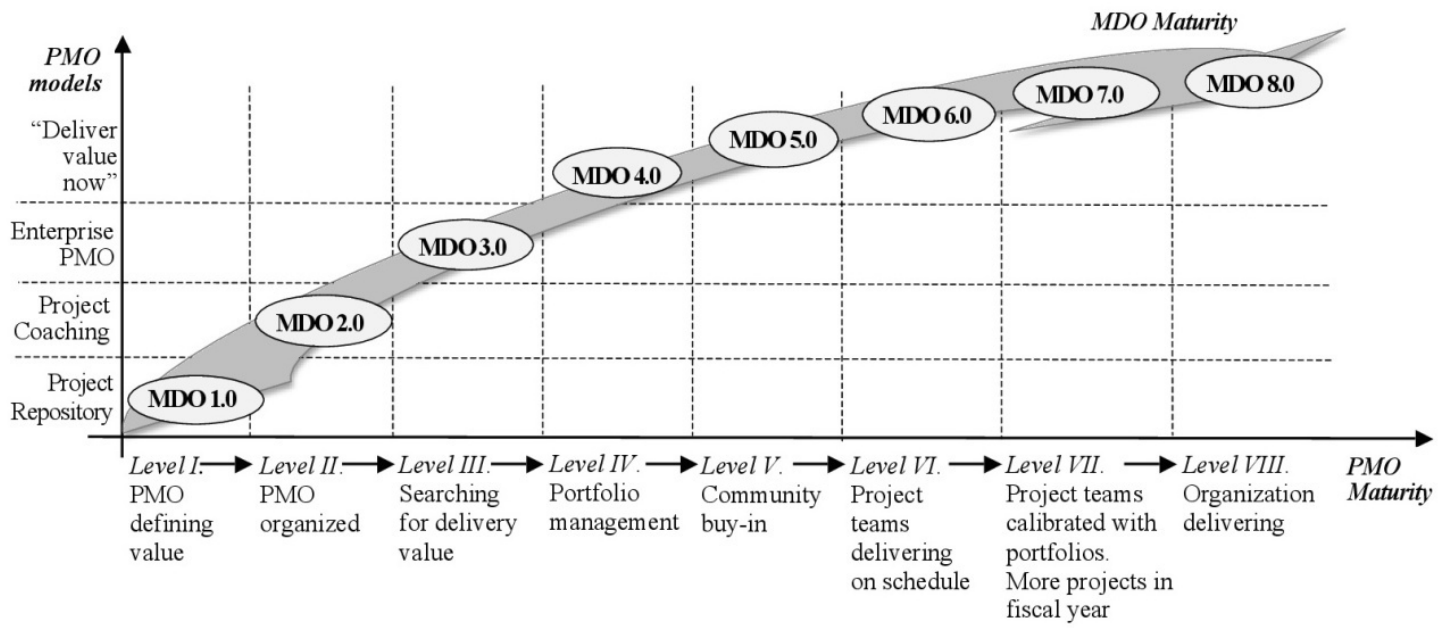

Figure 1. The conceptual scheme of Municipal Digital Office maturity

The issue of the functioning of MDO becomes relevant in circumstances where the online services of city projects and programs are significant.

\section{Conclusion}

The e-Government is a peculiar catalyst for the projects and programs of sustainable urban development. That is the way the cities around the world are developing different types of urbanization models, strategically relying on the use of digital technologies (Digital City, Intelligent City, Smart City). They are comprised of both digital government (delivery of public services) and digital democracy (citizen participation in governance). Cities need to develop their e-government potential by using GIS and creating synergies between public, private and civil society actors. EGovernment should cover the issues of social inclusion, economic development, and environmental protection, deploy public policies in pursuit of sustainability.

There are problems of integrating ICT at the level of the municipal management system, and its ability to handle the enormous information. In order to create a reliable basis for city e-

Vol. 5 No. 2 (2017)

Issue- June

ISSN 2347-6869 (E) \& ISSN 2347-2146 (P)

City-Governance: conceptualizing digital maturity model by Tetiana Fesenko, Galyna Fesenko Page no. 106-122 
Government, it is necessary to create the coordinate center with well-designed governance model, enabling continuous improvements. In this regard, a conceptual model of Municipal Digital Office (MDO) is proposed. The range of an organizational maturity in the coordination and development of smart-services is presented. Further, the maturity model is a measurable road map that MDO directors and municipality top management can use to self-evaluate their progress in the of smart services development.

\section{References}

- A Guide to the project management body of knowledge (PMBOK® Guide): Fifth Edition. (2013). Newtown Square: Project Management Institute.

- Chandra, S. (2016). E-Government in India: The need to ponder current e-government uptake. SOCRATES. 4(3), 35-46. Retrieved from http://socratesjournal.com/index.php/socrates/article/view/236.

- Estevez, E., Lopes, N. \& Janowski, T. (2016). Smart sustainable cities - reconnaissance study. United Nations University. Retrieved from https://joinup.ec.europa.eu/sites/default/files/smart_cities_report.pdf.

- Fesenko, G. and Fesenko, T. (2017). E-Government development strategies in the Eastern Partnership countries. SOCRATES. 5(1), 51-63. doi: 10.5958 / 2347-6869.2017.00007.3.

- Fesenko, T. and Fesenko, G. (2016). E-Readiness evaluation modelling for the monitoring programs EGovernment at the national level (for the example of Ukraine). Easten-European Journal of Interiorise Technologies. 3(81), 28-35. doi: 10.15587/1729-4061.2016.71606.

- Fesenko, T., Fesenko, G. and Bibik, N. (2017). The safe city: developing of GIS tools for gender-oriented monitoring (on the example Kharkiv city, Ukraine). Eastern-European Journal of Interiorise Technologies. 3/2(87), 25-33. doi: 10.15587 / 1729-4061.2017.103054.

- Holzer, M. \& Manoharan, A.P. (2016). Digital governance in municipalities worldwide (2015-16). Seventh global e-governance survey: a longitudinal assessment of municipal websites throughout the world. Newark: National Center for Public Performance. Retrieved from https://www.seoulsolution.kr/en/content/rutgers-spaa-digital-governance-municipalitiesworldwide-2015-16.

- Kaylor, C. H. (2005). E-government. The next wave of e-government: The challenges of data architecture. Bulletin of the American Society for Information Science and Technology. 31(2), 18-22. doi: 10.1002 / bult.1720310207.

- Kendall, G.I. and Rollins, S.C. (2003). Advanced Project Portfolio Management and the PMO: Multiplying ROI at Warp Speed. Boca Ration: J. Ross Publishing.

- Smart Cities: Governing, Modelling and Analysing the Transition. (2014). In Deakin M. (ed.). London: Routledge.

- UN-HABITAT 2004: Urban Governance Index: conceptual foundation and field test report. Global Campaign on Urban Governance; Global Urban Observatory.

Vol. 5 No. 2 (2017)

\section{Issue- June}


- UN-HABITAT 2015: E-Governance and urban policy design. Nairobi : UN-Habitat Copyright.

- United Nations E-Government Survey 2016: E-Government in Support of Sustainable Development. New York: Department of Economic and Social Affairs. Retrieved from http://workspace.unpan.org/sites/Internet/Documents/UNPAN96407.pdf.

\section{Cite this article:}

City-Governance: conceptualizing digital maturity model

\section{Citation Format: APA:}

Fesenko, T., \& Fesenko, G. (2017). City-Governance: conceptualizing digital maturity model. S O C R A T E S, 5(2), 106-122. Retrieved from http://socratesjournal.com/index.php/socrates/article/view/293

\section{For more citation formats visit:}

http://socratesjournal.com/index.php/socrates/rt/captureCite/293/0

\section{Indexing metadata is available online on:}

http://socratesjournal.com/index.php/socrates/rt/metadata/293/0

Vol. 5 No. 2 (2017)

\section{Issue- June}

